\title{
PHYTOCHEMICAL ANALYSIS, ANTIOXIDANT POTENTIAL, ANTIBACTERIAL ACTIVITY AND MOLECULAR CHARACTERIZATION OF Clerodendrum species
}

\author{
PRASAD M.P. *, SUSHANT S. AND CHIKKASWAMY B.K.
}

Sangenomics Research Labs, Bangalore-560071, Karnataka, India

*Corresponding Author: Email- prasad_m_p@hotmail.com

Received: September 08, 2012; Accepted: November 20, 2012

\begin{abstract}
Clerodendrum is widely distributed plant in India and its medicinal use has been mentioned in traditional Indian systems. In the present study six species of Clerodendrum (C. inerme, C. peniculatum, C. philippinum, C. phlomidis, C. serratum and C. villosum) were screened for the presence of phytochemicals and were found positive for Glycosides, Terpeniods, Anthraquinones, Flavonoids, Saponins, Tannins, Lignin, Phenol and Alkaloids. All the species showed Antioxidant potential for all the Antioxidant Assays tested (DPPH Assay, Reducing Power Assay and Total Antioxidant Activity). For DPPH assay maximum antioxidant activity was seen for $C$. inerme, and $C$. serratum showed maximum activity in Reducing Power Assay and Total Antioxidant Activity. The plant species were also analyzed to check for their Antibacterial Activity. Among the solvents (Chloroform, Ethanol, Methanol, Iso-amyl Alcohol and Propanol) used for extraction, the Iso-amyl Alcohol extract was found to be most active compared to other solvent extracts. B. subtilis and $S$. aureus were most sensitive among the tested pathogens. Proteus $\mathrm{sp}$ exhibited sensitivity towards most of the plant $\mathrm{sp}$ and for almost all solvent extracts. These findings can be used as prerequisite for Clerodendrum plant screening for bioactive compound for medicinal purposes. Genomic DNA was extracted from the fresh leaves of selected cultivars and PCR was performed by using RAPD primers to check the genetic diversity among these species. From the PCR generated fingerprint, dendrogram was plotted by cluster analysis of similarity matrix. Dendrogram constructed by cluster analysis of RAPD markers showed that $C$. inerme and $C$. serratum are closely related. As very little work has been done on molecular characterization of Clerodendrum sp. by RAPD technique, our finding can be used as prerequisite for plant breeding activities as well as for conservation of genetic resources.
\end{abstract}

Keywords- Clerodendrum, Antibacterial, Antioxidant, Phytochemical, RAPD

Citation: Prasad M.P., Sushant S. and Chikkaswamy B.K. (2012) Phytochemical Analysis, Antioxidant Potential, Antibacterial Activity and Molecular Characterization of Clerodendrum species. International Journal of Molecular Biology, ISSN: 0976-0482 \& E-ISSN: 0976-0490, Volume 3, Issue 3, pp.-71-76.

Copyright: Copyright@2012 Prasad M.P., et al. This is an open-access article distributed under the terms of the Creative Commons Attribution License, which permits unrestricted use, distribution and reproduction in any medium, provided the original author and source are credited.

\section{Introduction}

Many plants are found to contain chemical compounds, which are used as natural medicines to treat common bacterial infections. These medicinal plants have been regularly used in various system of Indian medicine because of minimal side effect and cost effectiveness which provide scientific support to the therapeutic use of the plants in tribal medicine [1]. The genus Clerodendrum $L$. is widely distributed in tropical and subtropical regions of the world and is comprised of small trees, shrubs and herbs. Many species of the genus have also been documented in traditional systems of medicine practiced in countries like India, China, Korea, Thailand and Japan [2]. A number of species from the genus Clerodendrum are documented in ancient texts for their antimicrobial action. Clerodendrum species showed antifungal activity and also exhibited antibacterial activity against bacterial pathogens [3,4]. Methanolic fraction of $C$. inerme is effective against $S$. faecalis and $B$. subtilis which are gram positive and three of the gram negative bacteria (K. pneumoniae, Proteus sp. and S. boydii) [5]. Roots and leaf extracts of Clerodendrum have been used for the treatment of rheumatism, asthma and other inflammatory diseases [6-10] and also possess sedative, antihypertensive and antidiabetic properties $[11,12]$. The present investigation is conducted for screening antibacterial compounds from natural resources as the existing drugs are getting less effective due to increased tolerance of microorganisms.

Antioxidants are compounds which quench molecular oxidation, and play a vital role in guarding the body defense mechanism against free radicals and reactive oxygen species, which are generated continuously in the body due to both normal metabolism and certain diseases $[13,14]$. Species like $C$. inerme have been used as antioxidant drugs in various indigenous systems of medicines [15]. When an imbalance occurs between oxidants and antioxidants in 
favor of the oxidants, then oxidative stress sets up which may lead to the aging process as well as to chronic diseases such as cancer and coronary heart disease [16]. Interest in the role of antioxidants in human health has prompted research in the fields of food science and medicinal herbs to assess the role of herbs as antioxidants [17]. In the present study Antioxidant potential of six Clerodendrum species is analyzed for identifying new antioxidant compounds. Global interest in oriental medicine and production of medicinal plants has grown even over the recent years. Developing molecular markers could be important for quality assessment in the medicinal industry [18]. The study of genetic relationships is a prerequisite for plant breeding activities as well as for conservation of genetic resources [19]. The main advantage of RAPD-PCR is the use of unique and short arbitrary primer for PCR amplification, without prior information about the sequence of DNA. Besides, it is more advantageous with respect to other similar molecular marker techniques such as the more recently introduced AFLP [20]. In fact, RAPD-PCR technology is less time consuming, cost effective and for DNA fingerprinting it does not required any radioactive reagents [21]. Until now very little work has been done on molecular characterization of Clerodendrum sp. by RAPD technique, the purpose of this study is to find out phytochemical content of Clerodendrum sp. and molecular characterization of these species by RAPD technique.

\section{Materials and Methods}

\section{Sample Collection}

Plant samples such as C. inerme, C. peniculatum, C. philippinum, C. phlomidis, C. serratum and C. villosum were collected from University of Agriculture, Bangalore, India.

\section{Solvent Extraction}

Plant leaves were dried under shade and dried leaves were crushed using mortar and pestle. The crushed plant material $(10 \mathrm{~g})$ was kept on rotary shaker along with $100 \mathrm{ml}$ of different solvents like Chloroform, Ethanol, Methanol, Iso-amyl alcohol and Propanol for $48 \mathrm{hrs}$. The extract was concentrated by solvent evaporation and used for antibacterial activity.

\section{Isolation of Microorganisms for Antibacterial Activity}

The pathogenic microorganism were isolated from clinical samples and indentified on the basis of morphological, biochemical and physiological characteristics according to Bergey's manual of determinative bacteriology. The isolated microorganisms were found to be. B. subtilis, Proteus sp., S. aureus, K. pneumoniae and S. typhi.

\section{Determination of Antibacterial Activity}

The antibacterial activity was determined by the agar well-diffusion method. Overnight grown bacterial culture was transferred to sterile Petri plate with Mulleher Hinton agar medium (HiMedia Laboratories Limited, Mumbai, India) and was spread with sterile spreader to create a lawn. Wells of $6 \mathrm{~mm}$ were punched into the previously seeded $\mathrm{MH}$ agar plates using sterile cork borer. About $50 \mu \mathrm{l}$ of the different solvent extract was placed in the wells and allowed to diffuse for $2 \mathrm{hrs}$. at $4^{\circ} \mathrm{C}$ and the plates were incubated at $37^{\circ} \mathrm{C}$ for $24 \mathrm{hrs}$. The activity was determined by measuring the diameter of the inhibition zones for each well and expressed in millimeter.

\section{Determination of Minimal Inhibitory Concentration (MIC)}

The extracts that exhibited considerable activity were used for MIC determination. The extracts of the test samples were tested in four dose levels of $10 \mu$ lo $40 \mu$ l. The overnight grown bacterial culture was transferred on $\mathrm{MH}$ agar plate and wells were punched out

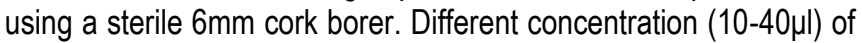
the extract was placed in separate wells and allowed to diffuse for $2 \mathrm{hrs}$. at $4^{\circ} \mathrm{C}$ and then the plates were incubated at $37^{\circ} \mathrm{C}$ for 24 hrs. The zone of inhibition was observed and the lowest amount of the test sample showing zone of inhibition was recorded as the MIC.

\section{Preliminary Phytochemical Analysis}

Phytochemical screening of plant extracts was done according to the standard procedure by Harbone [22]. All the prepared plant extracts were subjected to preliminary phytochemical screening for the presence of phenolic content, glycosides, anthraquinones, terpenoids, flavinoids, tannins, lignin and saponins.

\section{Antioxidant Assay \\ Extract Preparation for Antioxidant Activity}

For extraction, $5 \mathrm{~g}$ of the powdered sample was mixed with $50 \mathrm{ml}$ of methanol. The obtained extracts were filtered using whatman No.1 paper and the filtrate was collected, then methanol was removed by evaporation and residue was used for antioxidant assays.

\section{DPPH (1, 1-diphenyl-2-picrylhydrazyl) free radical scavenging assay}

Scavenging activity on DPPH was assessed according to the method reported by [23] with slight modification. Briefly, $0.5 \mathrm{ml}$ of extracts $(200$ to $1000 \mu \mathrm{g} / \mathrm{ml})$ was mixed with $3 \mathrm{ml}$ of methanolic solution of $0.1 \mathrm{mM} \mathrm{DPPH}$. Then the mixture was shaken thoroughly and incubated at room temperature for $30 \mathrm{~min}$ and absorbance was measured at $517 \mathrm{~nm}$ in a spectrophotometer.

\section{Reducing Power Assay}

The reducing power was determined by following method, $0.5 \mathrm{ml}$ of extracts $(200$ to $1000 \mu \mathrm{g} / \mathrm{ml})$ was mixed with $0.5 \mathrm{ml}$ of $0.2 \mathrm{M}$ phosphate buffer $(\mathrm{pH} 6.6)$ and $0.5 \mathrm{ml}$ potassium ferrocyanide (1\%). After incubating the mixture at $50^{\circ} \mathrm{C}$ for $20 \mathrm{~min}$., $0.5 \mathrm{ml}$ of $10 \%$ trichloroacetic acid was added, centrifugation was carried out at $3000 \mathrm{rpm}$ for $10 \mathrm{~min} .1 \mathrm{ml}$ of supernatant was mixed with $1 \mathrm{ml}$ of distilled water and $0.2 \mathrm{ml} \mathrm{FeCl} 3(0.1 \%)$ and the absorbance was measured at $700 \mathrm{~nm}$.

\section{Total Antioxidant Capacity}

The total antioxidant capacity was determined by the phosphormolybdenum method [24]. To $0.3 \mathrm{ml}$ of extract of different concentrations (200 to $1000 \mu \mathrm{g} / \mathrm{ml}$ ) was mixed with $3 \mathrm{ml}$ of reagent solution (0.6 M sulphuric acid, $28 \mathrm{mM}$ sodium phosphate and $4 \mathrm{mM}$ ammonium molybdate). The reaction mixture was incubated at $95^{\circ} \mathrm{C}$ for 90 min and cooled to room temperature. Absorbance was taken at $695 \mathrm{~nm}$ using a spectrophotometer against blank $(0.3 \mathrm{ml}$ distilled water in place of extract).

\section{DNA Isolation and PCR Amplification}

DNA was isolated from fresh leaf tissues as per the procedure 
described previously [25]. The polymerase chain reaction was carried out in final volume of $25 \mu$ l containing $100 \mathrm{ng}$ DNA, $3 \mathrm{U}$ of Taq DNA polymerase (Chromous Biotech, Bangalore), $2.5 \mathrm{mM} \mathrm{MgCl}$ (Chromous Biotech, Bangalore), 2.5mM each dNTPs (Chromous Biotech, Bangalore) and $100 \mathrm{p}$ mol of primers (GeNei, Bangalore). The DNA amplification was performed in the Corbett RG 6000 thermo cycler using the following conditions: complete denaturation $\left(94^{\circ} \mathrm{C}\right.$ for $\left.5 \mathrm{~min}\right), 10$ cycles of amplification $\left(94^{\circ} \mathrm{C}\right.$ for $45 \mathrm{sec}, 35^{\circ} \mathrm{C}$ for $1 \mathrm{~min}$ and $72^{\circ} \mathrm{C}$ for $1.5 \mathrm{~min}$ ) followed by 30 cycles of amplification $\left(94^{\circ} \mathrm{C}\right.$ for $45 \mathrm{sec}, 38^{\circ} \mathrm{C}$ for $1 \mathrm{~min}$ and $72^{\circ} \mathrm{C}$ for $\left.1 \mathrm{~min}\right)$ and the final elongation step $\left(72^{\circ} \mathrm{C}\right.$ for $\left.5 \mathrm{~min}\right)$. All PCR products were separated on $2 \%(\mathrm{w} / \mathrm{v})$ Agarose gel containing ethidium bromide $(0.5$ $\mu \mathrm{g} / \mathrm{ml})$. The gel was photographed with HP Alpha-imager.

\section{Data Analysis}

The RAPD profiles were analyzed based on the presence or absence of individual RAPD bands. The genetic distance was calculated by the coefficient of frequency similarity matrix. The matrix of genetic distance was used for grouping the Clerodendrum cultivars based on the dendrogram constructed by UPGMA (un-weighed pair group method with Arithmetic averages)

\section{Results and Discussion}

The antibacterial activity of six Clerodendrum species was determined in both gram positive and gram negative bacteria. The zone of inhibition produced by these extract against pathogenic bacteria is summarized in [Fig-1], [Fig-2], [Fig-3], [Fig-4], [Fig-5]. The isoamyl extract was most active against all the tested pathogens. Against $B$. subtilis highest zone of inhibition $(38 \mathrm{~mm})$ was produced by isoamyl extract of $C$. serratum. Against Proteus sp. highest zone of inhibition $(24 \mathrm{~mm})$ was produced by isoamyl extract of $C$. serratum and $C$. philippinum. Against $S$. aureus highest zone of inhibition $(39 \mathrm{~mm})$ was produced by isoamyl extract of $C$. villosum. Against $K$. pneumoniae highest zone of inhibition $(34 \mathrm{~mm})$ was produced by isoamyl extract of $C$. villosum. Against $S$. typhi highest zone of inhibition $(38 \mathrm{~mm})$ was produced by isoamyl extract of $C$. serratum.

All the six species of Clerodendrum exhibited diverse antimicrobial activity in the MIC assay at varied concentrations as summarized in [Table-1]. The Iso-amyl Alcohol extract was most active compared to other solvent extracts and $B$. subtilis and $S$. aureus were most sensitive among tested microorganism. For overall result, antibacterial activity of nearly all plant for almost all solvent extract has been seen for Proteus sp.

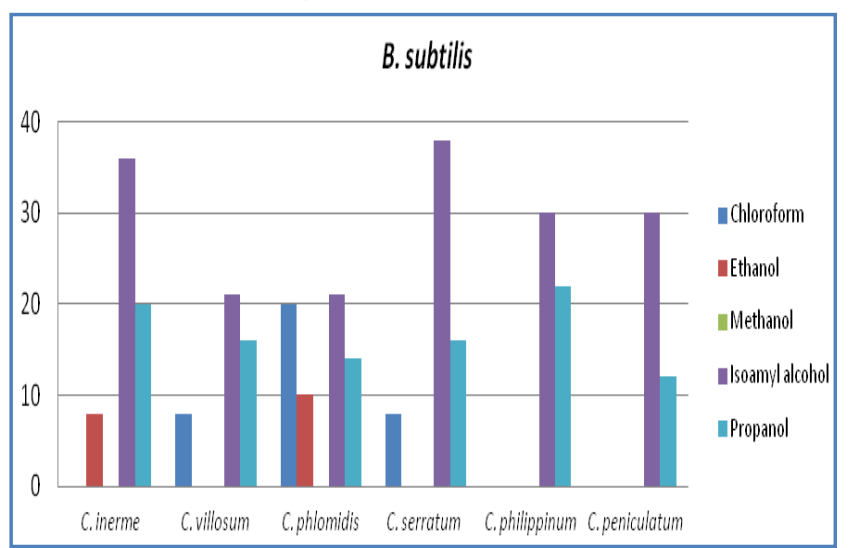

Fig. 1- Antibacterial of Clerodendrum against B. subtilis.

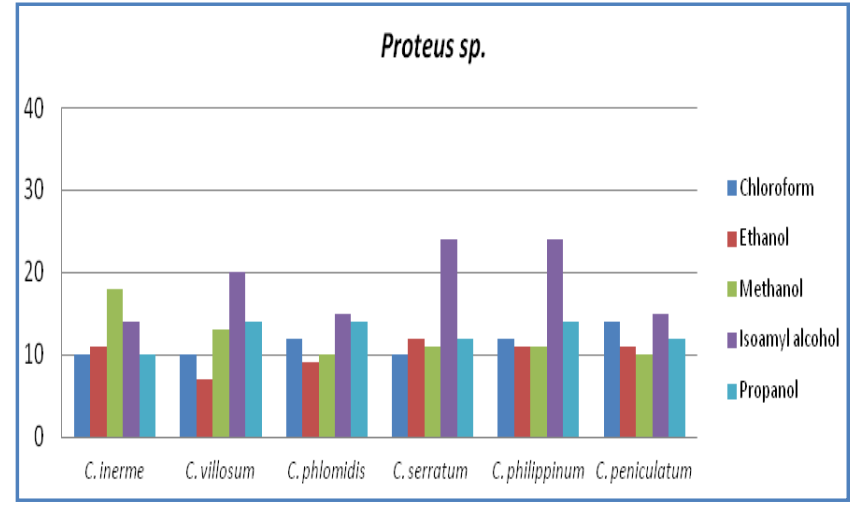

Fig. 2- Antibacterial of Clerodendrum against Proteus sp.

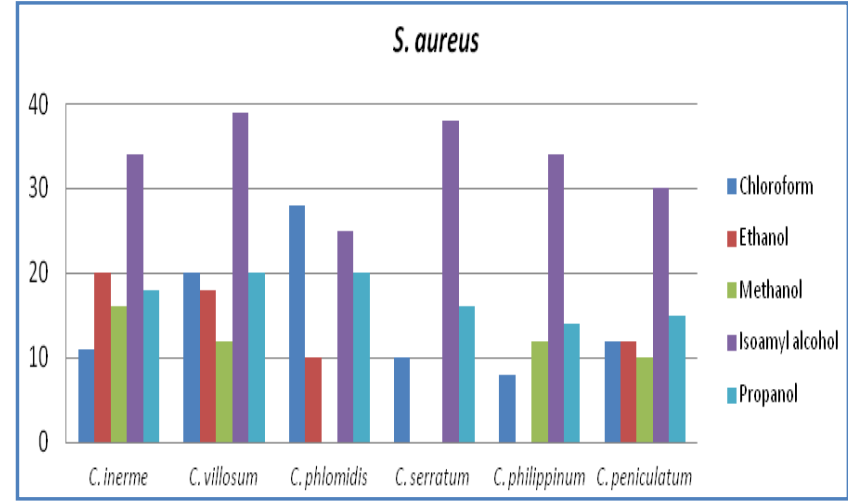

Fig. 3- Antibacterial of Clerodendrum against S. aureus.

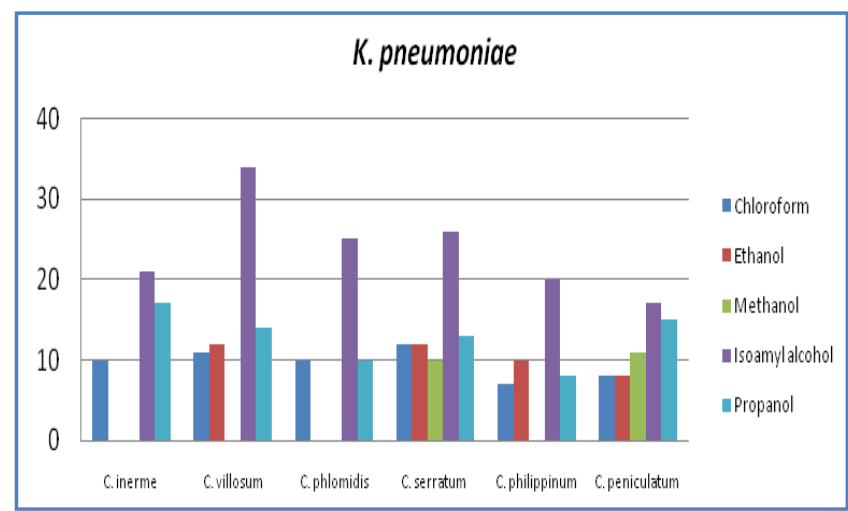

Fig. 4- Antibacterial activity of Clerodendrum against $K$. pneumoniae

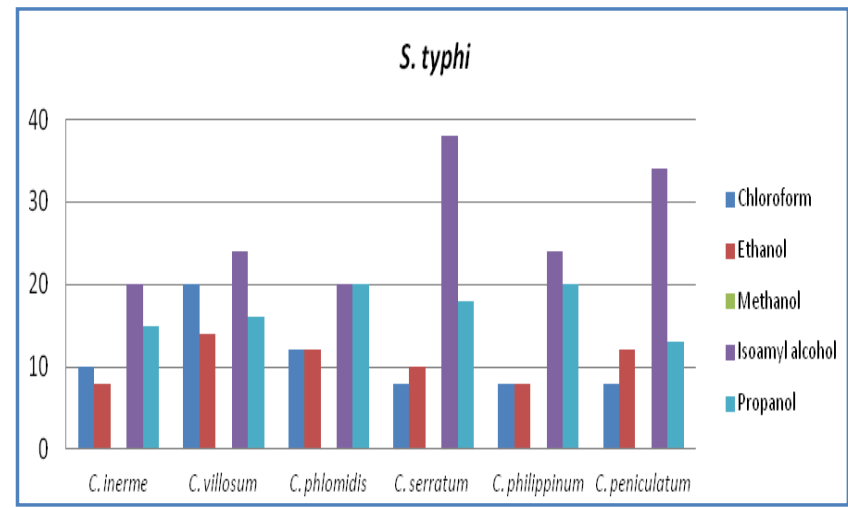

Fig. 5- Antibacterial of Clerodendrum against S. typhi. 
Table 1- Minimal Inhibitory Concentration of Clerodendrum Species

\begin{tabular}{|c|c|c|c|c|c|}
\hline Extraction & \multicolumn{5}{|c|}{ Minimum Inhibitory Concentration } \\
\hline Solvent and & \multicolumn{5}{|c|}{ Pathogen } \\
\hline \multicolumn{6}{|c|}{ Chloroform Extract of } \\
\hline C. inerme & - & 40 & 40 & - & - \\
\hline C. villosum & - & 40 & 40 & - & 40 \\
\hline C. phlomidis & 20 & 30 & 30 & 40 & - \\
\hline C. serratum & - & 40 & - & - & - \\
\hline C. philippinum & - & 30 & - & - & - \\
\hline C. peniculatum & - & 30 & - & - & - \\
\hline \multicolumn{6}{|c|}{ Ethanol Extract of } \\
\hline C. inerme & - & 40 & 30 & - & - \\
\hline C. villosum & - & - & 30 & 40 & 40 \\
\hline C. phlomidis & - & - & - & - & 40 \\
\hline C. serratum & - & 40 & - & 40 & - \\
\hline C. philippinum & - & 40 & - & - & - \\
\hline C. peniculatum & - & 40 & 40 & - & 40 \\
\hline \multicolumn{6}{|c|}{ Methanol Extract of } \\
\hline C. inerme & - & 30 & 30 & - & - \\
\hline C. villosum & - & 40 & 40 & - & - \\
\hline C. phlomidis & - & - & - & - & - \\
\hline C. serratum & - & 40 & - & - & - \\
\hline C. philippinum & - & 40 & 40 & - & - \\
\hline C. peniculatum & - & - & - & - & - \\
\hline \multicolumn{6}{|c|}{ Iso-amyl Alcohol Extract of } \\
\hline C. inerme & 10 & 30 & 10 & 20 & 20 \\
\hline C. villosum & 30 & 20 & 10 & 10 & 20 \\
\hline C. phlomidis & 10 & 30 & 20 & 20 & 30 \\
\hline C. serratum & 10 & 10 & 10 & 20 & 10 \\
\hline C. philippinum & 10 & 10 & 10 & 20 & 10 \\
\hline C. peniculatum & 10 & 30 & 10 & 20 & 10 \\
\hline \multicolumn{6}{|c|}{ Propanol Extract of } \\
\hline C. inerme & 30 & - & 30 & 30 & 40 \\
\hline C. villosum & 40 & 40 & 30 & 40 & 40 \\
\hline C. phlomidis & 40 & 40 & 30 & - & 30 \\
\hline C. serratum & 40 & 40 & 40 & 40 & 30 \\
\hline C. philippinum & 30 & 40 & 40 & - & 30 \\
\hline C. peniculatum & 40 & 40 & 40 & 40 & 40 \\
\hline
\end{tabular}

Preliminary phytochemical screening of C. inerme, C. peniculatum, C. philippinum, C. phlomidis, C. serratum and C. villosum showed the presence of Glycosides, Terpeniods, Anthraquinones, Flavonoids, Saponins, Tannins, Lignin, Phenol and Alkaloids which account for their usefulness as medicinal plants. Flavonoids, Saponins, Lignin and Phenol were present in all six species; whereas, Glycosides, Terpeniods, Anthraquinones, Tannins and Alkaloids were present in most of the species but not all. The detailed description of phytochemical distribution among each of the Clerodendrum sp. is shown in [Table-2].

Table 2- Phytochemical screening of leaf of Clerodendrum Sp.

\begin{tabular}{|c|c|c|c|c|c|c|}
\hline & $\begin{array}{c}\text { c. } \\
\text { inerme }\end{array}$ & $\begin{array}{c}\text { C. } \\
\text { peniculatum }\end{array}$ & $\begin{array}{c}\text { C. } \\
\text { philippinum }\end{array}$ & $\begin{array}{c}\text { C. } \\
\text { phlomidis }\end{array}$ & $\begin{array}{c}\text { C. } \\
\text { serratum }\end{array}$ & $\begin{array}{c}\text { C. } \\
\text { villosum }\end{array}$ \\
\hline $\begin{array}{l}\text { Cardiac } \\
\text { Glycosides }\end{array}$ & +ve & -ve & -ve & -ve & +ve & -ve \\
\hline Terpeniods & $-v e$ & -ve & -ve & -ve & +ve & +ve \\
\hline $\begin{array}{l}\text { Anthraqui- } \\
\text { nones }\end{array}$ & +ve & +ve & +ve & +ve & -ve & -ve \\
\hline Proteins & +ve & +ve & +ve & +ve & +ve & +ve \\
\hline Flavonoids & +ve & +ve & $+v e$ & +ve & +ve & + ve \\
\hline Saponins & +ve & +ve & +ve & +ve & +ve & +ve \\
\hline Tannins & +ve & +ve & -ve & $-v e$ & +ve & + ve \\
\hline Lignin & +ve & +ve & +ve & +ve & +ve & +ve \\
\hline Phenol & +ve & +ve & +ve & +ve & +ve & +ve \\
\hline Alkaloids & -ve & -ve & $+v e$ & +ve & +ve & -ve \\
\hline
\end{tabular}

In the DPPH method the absorbance was measured and the percent inhibition of the DPPH radical by Clerodendrum was calculated based on the measured absorbance. Antioxidant capacities in series of concentrations for Clerodendrum was used for calculating the percentage of antioxidant activity as showed in [Fig-6]. All species of Clerodendrum showed good antioxidant activity. In the Reducing Power assay, C. inerme showed maximum antioxidant activity followed by $C$. serratum as compare to others [Fig-7]. In Total Antioxidant Capacity assay [Fig-8], the maximum antioxidant activity is shown by $C$. serratum.

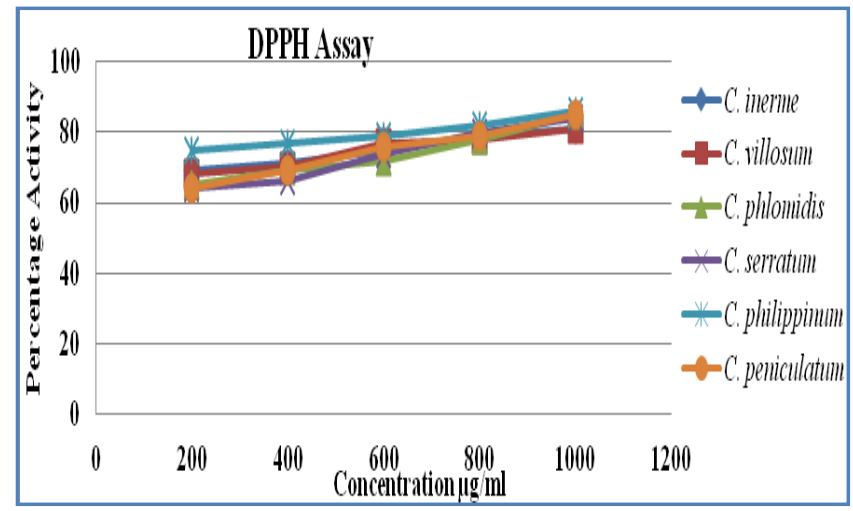

Fig. 6- Antioxidant Activity of Clerodendrum by DPPH Assay

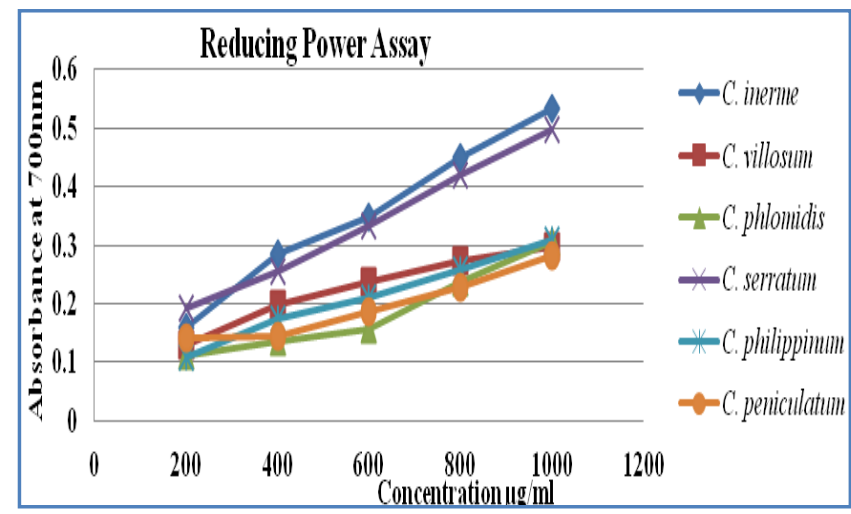

Fig. 7- Antioxidant Activity of Clerodendrum by Reducing Power Assay

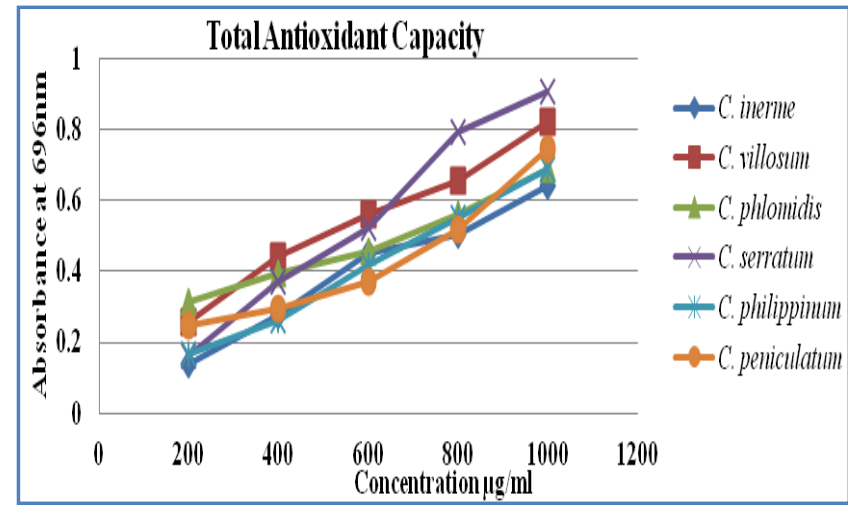

Fig. 8- Antioxidant Activity of Clerodendrum by Total Antioxidant Capacity

Free radicals causes major health problems such as Cancer, Alzheimer's disease, Cardiovascular Diseases, Cataract, Rheumatoid 
Arthritis and other degenerative diseases associated with aging, therefore Antioxidants can be beneficial to neutralize free radicals before they can attack cells and hence prevent damage to cell proteins, lipids and carbohydrates.

To determine genetic diversity, 10 primers (GeNei RPI-1 to GeNei RPI-10) were used. Among ten primers used, two primers (GeNei RPI-3 and GeNei RPI-4) gave the best distinguishable band pattern as shown in [Fig-9a], [Fig-9b].

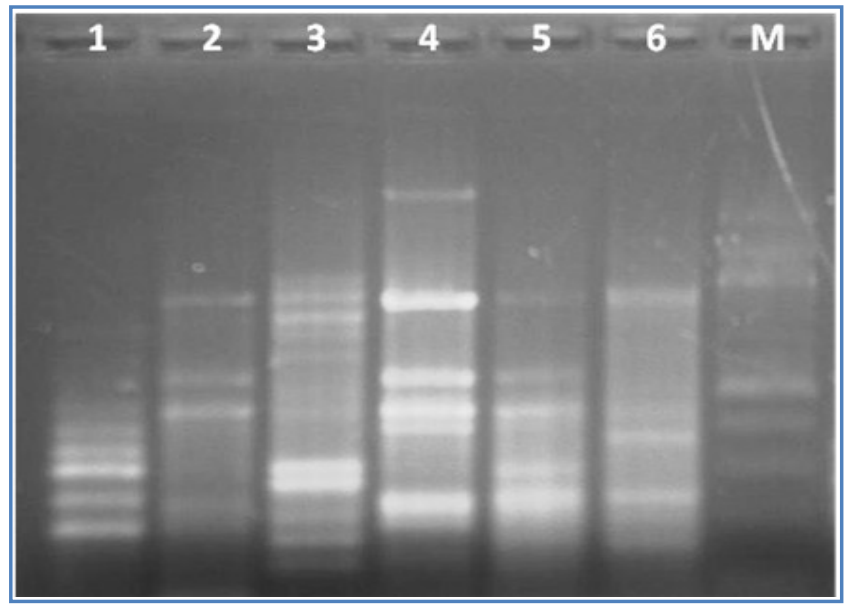

Fig. 9a- RAPD profiles of six selected cultivars obtained with $\mathrm{Ge}$ Nei RPI-3

1. C. inerme, 2. C. peniculatum, 3. C. philippinum, 4. C. phlomidis, 5. C. serratum, 6. C. villosum and M. 100bp marker. A. GeNei RPI3 B. GeNei RPI-4.

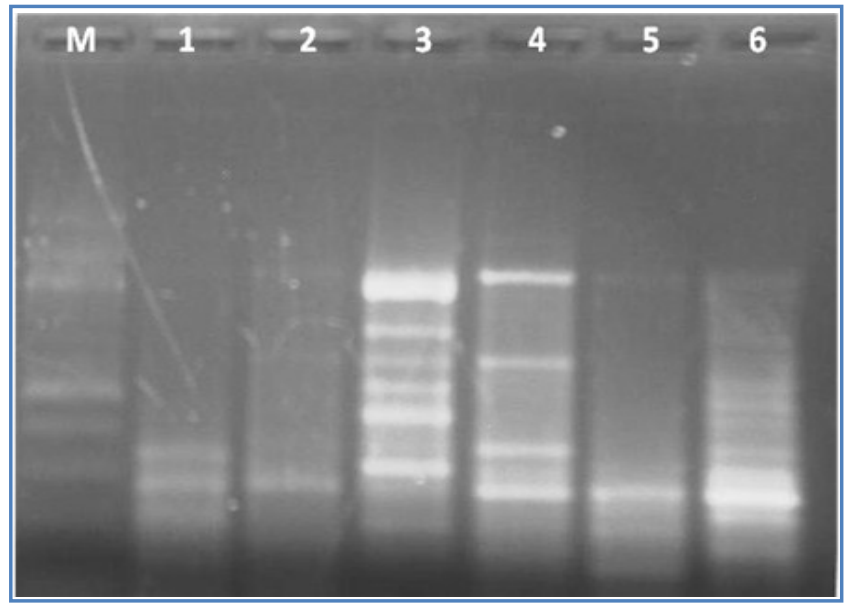

Fig. 9b- RAPD profiles of six selected cultivars obtained with GeNei RPI-4

1. C. inerme, 2. C. peniculatum, 3. C. philippinum, 4. C. phlomidis, 5. C. serratum, 6. C. villosum and M. 100bp marker. A. GeNei RPI3 B. GeNei RPI-4.

Dendrogram analysis of the DNA fingerprint generated by GeNei RPI-3 and GeNei RPI-4 primer is shown in [Fig-10], [Fig-11] respectively. Similarity Matrix showed that $C$. inerme and $C$. serratum are closely related. C. inerme and C. serratum showed $100 \%$ similarity for primer GeNei RPI-4. C. peniculatum and C. phlomidis are more closely related based on the similarity matrix by GeNei RPI-3 primer.

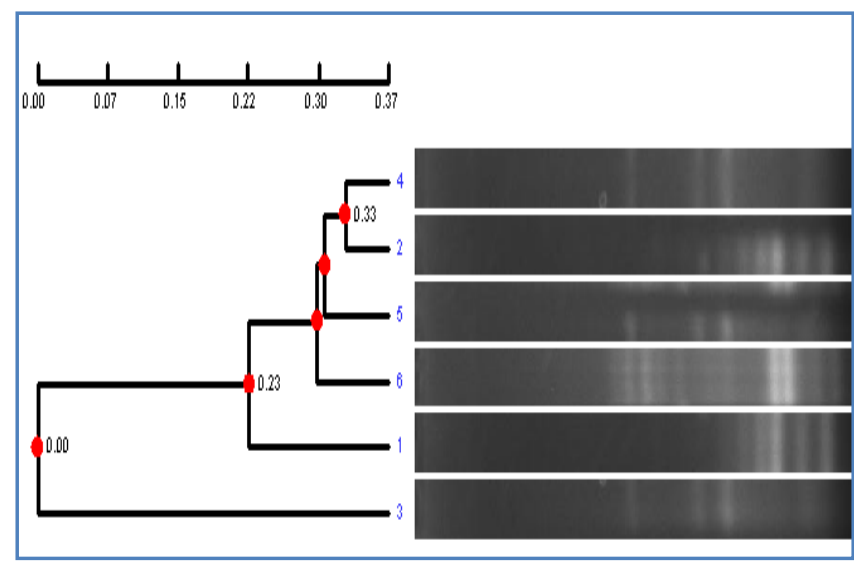

Fig. 10- Dendrogram of six samples for primer GeNei RPI-3

1. C. inerme, 2. C. peniculatum, 3. C. philippinum, 4. C. phlomidis, 5. C. serratum, 6. C. villosum

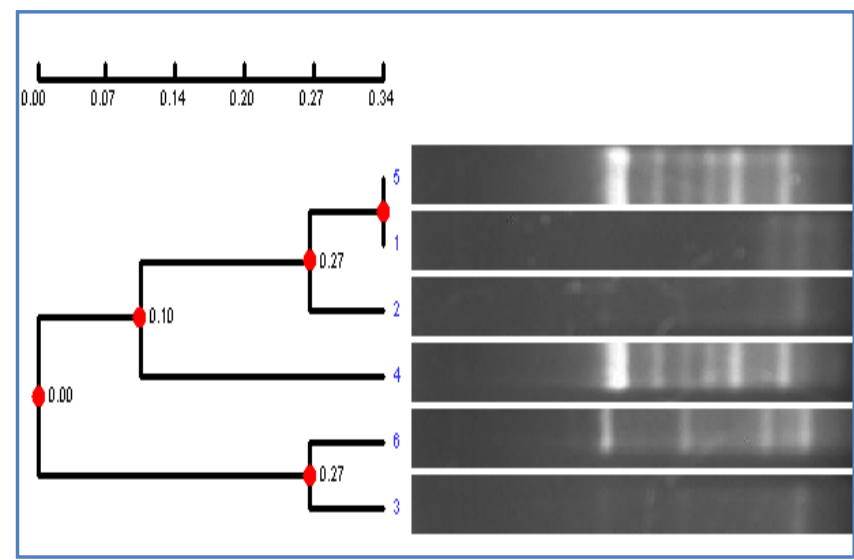

Fig. 11- Dendrogram of six samples for primer GeNei RPI-4 1. C. inerme, 2. C. peniculatum, 3. C. philippinum, 4. C. phlomidis, 5. C. serratum, 6. C. villosum

\section{Conclusion}

The selected Clerodendrum sp. contains phenolic compounds, glycosides, anthraquinones, terpenoids, flavinoids, tannins, lignin and saponins. The potential for developing Antioxidants from Clerodendrum plants appear rewarding as it may lead to the development of novel phytomedicine. Also, screening of Clerodendrum can make a way for identification of new important antimicrobial components. Further study can be done for determination of toxicity, side effects and pharmaco-kinetic properties of isolated antimicrobial compounds. Molecular characterization by RAPD PCR revealed that $C$. inerme and $C$. serratum are closely related and share more common DNA sequence among all six species. Molecular study data can be served as prerequisite for plant breeding activities as well as for conservation of genetic resources. From the current phytochemical data it can be conclude that Clerodendrum $s p$. may be utilize as a source of ingredient to the pharmaceutical industries for the development of new bioactive compound.

\section{References}

[1] Rajlakshmi D., Banerjee S.K., Sood S. and Maulik S.K. (2003) Journal of Pharmacy and Pharmacology, 55(12), 1681-1686. 
[2] Moldenke H.N. (1985) Phytologia, 57, 334-365.

[3] Sharma S.K. and Singh V.P. (1979) Indian Drugs Pharmaceutical Industry, 14, 3-6.

[4] Chahal J.K., Sarin R. and Malwal M. (2010) International Journal of Pharma and Bio Sciences, 1(4), 219-223.

[5] Khan A.V. and Khan A.A. (2006) Oriental Pharmacy and Experimental Medicine, 4, 306-311.

[6] Choi J.H., Wang W.K. and Kim H.J. (2004) Archives of Pharmacological Research, 27, 189-193.

[7] Hazekamp A., Verpoorte R. and Panthong A. (2001) Journal of Ethnopharmacology, 78, 45-49.

[8] Kanchanapoom T., Chumsri P., Kasai R., Otsuka H. and Yamasaki K. (2005) Journal of Asian Natural Products Research, 7, 269-272.

[9] Kang D.G., Lee Y.S., Kim H.J., Lee Y.M. and Lee H.S. (2003) Journal of Ethnopharmacology, 89, 151-154.

[10]Panthong D., Kanjanapothi T., Taesotikul T. and Wongcomea V. (2003) Journal of Ethnopharmacology, 85, 151-156.

[11]Khan M.A. and Singh V.K. (1996) Fitoterapia, 67, 416-421.

[12]Singh V.P., Sharma S.K. and Khan V.S. (1980) Indian Drugs and Pharmaceutical Industry, 5, 7-12.

[13]Gate L., Paul J., Ba G.N., Tew K.D. and Tapiero H. (1999) Biomedicine and Pharmacotherapy, 53, 169-180.

[14]Gutteridge J.M.C. and Halliwell B. (2000) Annals of the New York Academy of Sciences, 899, 136-147.

[15]Masuda T., Yonemori S., Oyama Y., Takeda Y., Tanaka T. and Andoh T. (1999) Journal of Agriculture and Food Chemistry, $47,1749-1754$.

[16]Benzie I.F. (2000) European Journal of Nutrition, 39, 53-61.

[17]Manigauha A., Huma Ali and Uma-maheshwari M. (2009) Journal of Pharmacy Research, 2(3), 491-494.

[18]Harisaranraj R., Prasitha S., Saravana B. and Suresh K. (2008) Ethnobotanical Leaflets, 12, 609-613.

[19]Mohammad A., Reza D. and Abbas H. (2012) Revista Ciência Agronômica, 43(2), 312-320.

[20]Vos P., Hogers R., Bleeker M., Reijans M., Van De Lee T., Horenes M., Fiujters A., Pot J., Pelerman J., Kuiper M. and Zabeau M. (1995) Nucleic Acids Resrarch, 23, 4407-4414.

[21]Luigi D.M., Pietro S., Castrese E., Domenico C., Francesco S. and Bruna L. (2006) European Food Research and Technology, 223(02), 273-281.

[22]Harbone J.B. (1998) Phytochemical Methods: A Guide to Modern Techniques of Plant Analysis, Chapman and Hall London.

[23]Blois M.S. (1958) Nature, 181, 1199-1200.

[24]Brain K.R. and Turner T.D. (1975) The practical evaluation of phytopharmaceuticals, Wright Science Technical, Bristol, 8182.

[25]Khanuja S.P.S., Shasany A.K., Darokar M.P. and Kumar S. (1999) Plant Molecular Biology Reporter, 17, 1-7. 